\title{
Clickers in EFL Classrooms: Evidence from Two Different Uses
}

\author{
Unal Cakiroglu \\ Karadeniz Technical University, Turkey \\ Fatih Erdogdu \\ Karadeniz Technical University, Turkey \\ Seyfullah Gokoglu \\ Kastamonu University, Turkey
}

Received: 06.06.2017

Accepted: 08.03.2018

Published: 13.04 .2018

\begin{abstract}
Clickers as electronic response systems allow students to respond instantly to questions. The aim of this study is to compare the effects of using clickers on student participation during different periods of EFL courses. The intervention was implemented in questionresponse sessions of an EFL course at a secondary school. A quasi-experimental design was used in which twenty participants were assigned to two groups, Group A $(n=10)$ and Group B $(n=10)$. The implementation process is divided into three periods. In the preparation period, both of the groups did not use clickers, in the first period while the Group A used clickers, Group B continued without using clickers in the lessons. Then in the second period; in contrary, Group A and Group B students changed the roles in using the clickers; that is Group B started with clickers in the second period and Group A followed the lesson without clickers. When the clickers used the students' participation rates were determined by clicker system records and an observation form is used when non-clickers strategies were used. As a result, even if they used clickers in different time periods both Groups $A$ and $B$ increased their participation rates while using clickers. Moreover, when the students in Group A were non-clickers, their correct answer rates were decreased. In contrast, when the students in Group B were non-clickers, their correct answer rates were increased. Results showed that even after students ceased to use clickers, positive effects on participation continued; however, the quality of the students' answers declined. Along with the study findings, suggestions for clickers use in various periods of the courses are included.
\end{abstract}

Keywords: Participation; Clickers; Traditional response strategies; Language teaching; EFL classroom

\section{Introduction}

Participation in the classroom is somewhat related to the learning. Especially in large classrooms, instructors often face difficulties gaining students' attention and they generally direct students to raise their hands for a given question or to use response cards for multiplechoice questions and encouraging their participation. Thus various approaches are implemented in order to increase students' participation. Since, providing opportunities for 
meaningful engagement in classroom activities is difficult, instructors are encouraged to use active student response methods (Martyn, 2007) such as electronic response systems (ERS) or "clickers" (Lantz, 2010). Most commonly implemented in higher education today, clickers are also gaining popularity in primary and secondary schools (Mun, Hew, \& Cheung, 2009).

Through real-time feedback provided by clickers, instructors have more opportunities to manage the course (Kay \& LeSage, 2009) while students have opportunities to control their learning level (Sun, 2014). Since traditional response approaches in classrooms are considered limited for student participation (Schell, Julie, Lukoff, \& Mazur, 2013), clickers are suggested with their potential for increasing participation (Scott, 2014). Using clickers allows teachers to gather real-time feedback about students' responses to multiple-choice questions (Lasry, 2008). In order to determine how and when to use clickers for high-level participation, this study focuses on clicker use for participation in classroom. Accordingly, the following subsections briefly discuss the relation between students' participation and clicker use in the instructional processes.

\section{Participation}

Participation is generally defined taking part in class work, homework, activity in the classroom and active in the learning process (Reschly \& Christenson, 2006). Since, student participation plays a crucial role in learning performance; various descriptions of participation have been assigned depending on the context (Heaslip, Donovan, \& Cullen, 2014). Dancer and Kamvounias (2005) defined five distinct indicators for participation: preparation, contribution to discussion, group skills, communication skills, and attendance. Students generally consider participation as various types of involvement, whereas tutors perceive it as in-class discussion (Rocca, 2010). It is difficult to measure participation for researchers because of the various definitions and indicators. In this sense, analyzing responses for the answers in instructional processes provide quantitative data which may be a useful for instructors and can be easily obtained. In fact, clickers can provide this information and also the quality of the responses (number of true/false responses). By itself, a clicker cannot solve participation problems at this point; hence, integrating teaching strategies and the potential of clickers may support the continuity of student participation. Additionally, other elements can affect participation, such as the teacher's instructional style, the lesson dynamics, and the duration of the lessons. In this sense, Forrest (2011) reported that student classroom participation levels when using clickers were generally high only at particular lesson periods. This idea implies that various instructional approaches may affect participation as well as using clickers.

\section{Clickers as ERS Tools}

In the traditional instructional processes in the classrooms, traditional response strategies (raising hands, response cards etc.) have provided only a limited number of students the opportunity to answer questions simultaneously. In this circumstance, clickers may allow all students to answer to all questions. Additionally, clickers advantageously provide instant feedback to each student (Scott, 2014), allow students to be active during lectures (Snyder, 2003). Moreover, they helped to maintain students' interest and encouraged participation and interaction (Bartsch \& Murphy, 2011; Heaslipet al., 2014) and also using clickers is enjoyable for students (Egelandsdal \& Krumsvik, 2017). Furthermore, clickers can provide 
information for instructors about how students learned the subject before moving to a new subject (Stuart, Brown, \& Draper, 2004; Yourstone, Kraye, \& Albaum, 2008). Therefore, clicker data might be useful for analyses and assessments of students' classroom behaviors. In addition to the advantages provided by clickers (interaction, instant feedback, participation, enjoyment, learning performance etc.), it is noteworthy that how they effect during the lessons. In this regard, it is argued that one remarkable educational benefit of clickers is related to participation and engagement. A considerable effort has been invested in the use of clickers about learning, enjoyment, satisfaction and students' attendance (Robinson, 2006; Blood \& Neel, 2008; Mayer et al., 2009). While prior work provides compelling evidence that clickers are useful in participation, it leaves several open questions about the approaches for this kind of participation in the lessons. Regarding this gap, it is thought that this study will contribute in terms of the effect of the use of clickers on participation in particular lesson periods. In this line of reasoning, Ross, Morrison \& Lowther (2010) suggest that integrating technology as a learning tool in classroom instruction and teaching students to become skilled users of these novel technologies.

Moreover, clickers have been used in activities of various courses -mathematics, physics, and arts- but one course particularly favoring clicker use is EFL. In regard to various courses, Keough (2012) suggested that a significant gap still exists in educational participation issues related to clickers. Although some efforts have been made and some benefits have been reported, an important question about clickers remains to be investigated: "When and how clickers should be used?"

\section{Clickers in EFL Classrooms}

Unlike some courses identified above, EFL classes are generally small, so it gives teachers to use clickers' potential in different ways. That is to say, clickers are used during various activity periods of the instructional process. For instance, in a grammar course in which clickers are used, continuous implementation is necessary for participation (Marlow, 2010). In addition, there are also studies that you need to use clickers in quizzes, tests, at the end or at the specific period of the lesson, rather than having to apply clickers continuously (Carnaghan \& Webb, 2007; Cardoso,2011; Chui, Martin, \& Pike, 2013). It is obvious that clickers can be used at different period of the lessons but there is a little volume of evidence about the use of clickers in various periods of the instructional process.

In this sense, many efforts are ongoing on clicker use in higher education settings (Carnaghan \& Webb, 2007; Nelson \& Hauck, 2008; Morse et al., 2010; Carla, Thomas, Thomas, \& Philip, 2011). However, in regard to educational levels, Mun et al. (2009) suggested that more research would facilitate better understanding concerning how clickers affect student participation in K-12 levels; hence, the period of clicker use may also provide crucial hints for their efficacy in EFL courses.

Previous studies have shown that clickers have been implemented at different levels and in different courses with various instructional approaches. Since studies on clickers have taken various approaches, studies on EFL classes in which clickers were used along with traditional response strategies are somewhat limited (Lee \& Ohh, 2014). Thus, hypothesizing that students who used clickers first and then began traditional response strategies and students who adopted the converse approach may have different participation outcomes in the lessons. 


\section{Research Questions}

Given the foregoing background, this study compared the implementation of clicker use during different periods of EFL courses and provided some suggestions about using clickers in EFL activities. The study attempted to answer the following research questions:

- How does using clickers during various periods of the instructional process affect student participation?

- Does the quality of participation in EFL courses vary between clicker and non-clicker sessions?

\section{Method}

To evaluate the effectiveness of the clickers, a quasi-experimental design by dividing the participating students into two groups was conducted.

\section{Participants}

Twenty $5^{\text {th }}$-grade students (12 females, 8 males; age range $11-12$ years; living in eastern region of Turkey, high socioeconomic status) who were enrolled in an EFL classroom at a private secondary school participated in this study. The participants were separated into two groups: Group A ( 5 males, 5 females) and Group B ( 3 males, 7 females). For both groups, an EFL teacher conducted the instructional process through the same activities and teaching methods. None of the participants had previous experience of using clickers. Additionally, during this implementation, the participants did not use clickers in other courses. All participants had taken basic EFL course the previous year.

\section{Design}

In this study, for the first two weeks (a preparation period), the groups did not use clickers; instead, they used traditional response strategies. In the third and fourth weeks (First Period), Group A used clickers, whereas Group B did not. Then, in the fifth and sixth weeks (Second Period), the two groups swapped the roles in using clickers. Figure 1 summarizes the process of clicker use. 


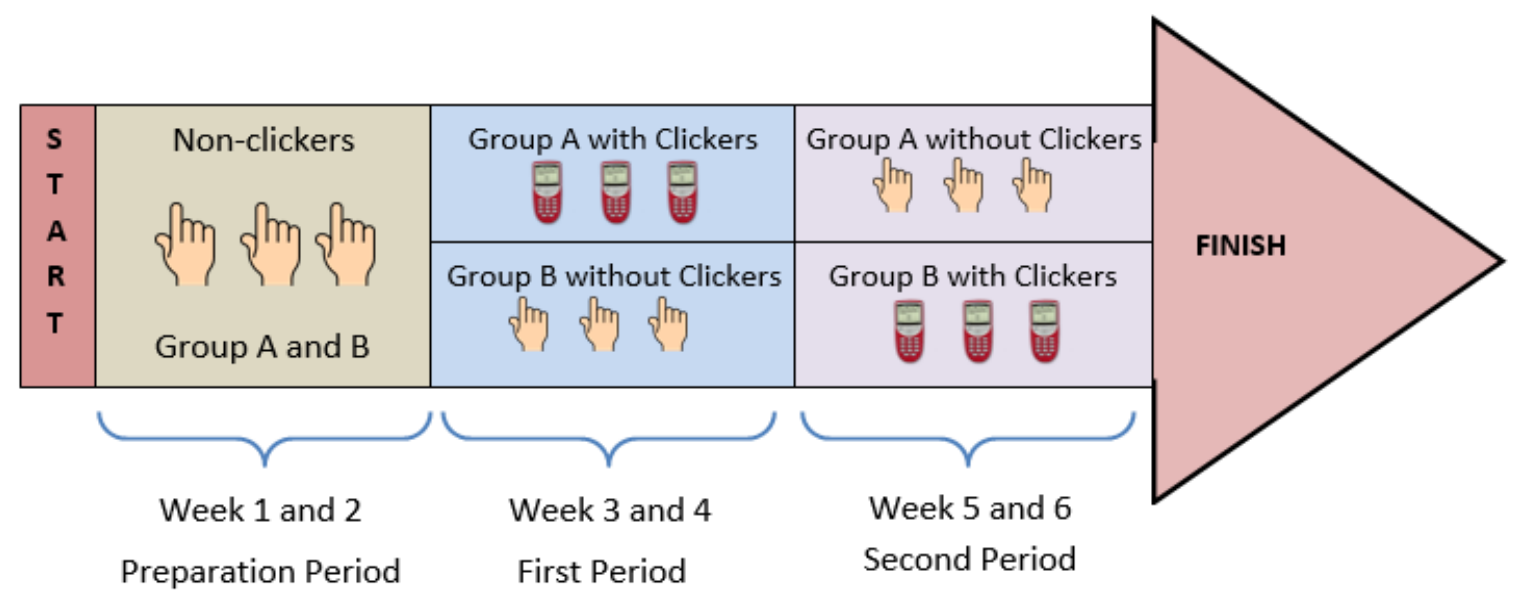

Figure 1. Design of the Study

\section{Process}

Before the study's implementation, technological infrastructure was set up in the classroom (e.g., installing Wi-Fi and software for clickers, loading questions to the clicker software). Furthermore, this study's researchers developed an observation form to determine the participation level of students not using clickers. The intervention was implemented for six weeks (18 lesson hours) under the topic "Likes \& Dislikes." The students received speaking discussion, vocabulary, and writing practice lessons. Activities were generally conducted via a question-response technique in both study groups. Group A responded to questions via clickers, whereas Group B used traditional response strategies. For all lessons, the instructor provided feedback according to the students' responses, and multiple-choice questions asked by the instructor were related to the topic.

During the preparation period (the first two weeks) of instruction, since none of the groups used clickers, d Groups A's and Group B's initial participation levels were revealed through classroom observation. After the second week, Group A-"clicker users"-implemented the technology. During the first experimental period (third and fourth weeks), the students in Group A answered questions via clickers, whereas the students in Group B were "non-clickers" who used traditional responses (e.g., raising their hands, standing up, asking questions, nodding their heads, making body movements, eye contact). After the fourth week, clicker users (Group A) did not use clickers during the second experimental period (fifth and sixth weeks) but non-users (Group B) did. It was not easy for the teacher to keep clickers and nonclickers in separate groups and do not interact in the same classroom. To do this, the teacher explained the aim of clickers' uses and the students were given clickers randomly. The teacher generally took position in the classroom physically separating the two groups namely the teachers' desk was located at the middle of the classroom. Thus, while clicker users were located on the one side of the teacher the other side was non-clickers. In this circumstance the interaction among the groups were impeded.

The EFL teacher used instructional strategies depending on students' responses in the classroom. He taught concepts, vocabulary, dialogs, listening activities, etc. with question-andresponse cycles. He provided opportunities for students to discuss about their responses by 
explaining and providing reasons for them. Taking part in classroom discussions, students could express their comments and opinions.

\section{Data Collection and Analysis}

Two different data collection tools; observation forms and clicker records were used to examine participation of students in the classroom. Using the observation form to gather traditional responses, the observer recorded all students' raising of hands, standing up, commenting, questioning, and the other behaviors. The correctness of the responses is also determined. While developing the observation form, expert opinions were taken into consideration. By using observation form, we could easily gather whether the behaviors reflecting traditional responses were exhibited or not. Thus, the participation rates (number of responses) and quality of participation (number of correct answer) were obtained and compared by applying descriptive analysis. For clicker users, the number of students answering a question and numbers of correct answers were recorded on clicker software. Data were analyzed descriptively and illustrated in graphical format. In addition, the answers given by the two groups were compared by using the non-parametric Mann-Whitney test for the experiments including the first and second period. Graphics functioned to compare implementations of clickers during different lesson periods and to compare participation between clickers and non-clickers in each group. They are also useful to illustrate changes in participation rates and quality of responses for each student.

\section{Results}

The results were organized as identifying changes in participation for Groups A and B, comparing the two groups, and addressing the quality of each group's responses.

\section{Participation in Different Periods of the Lessons}

The students in Group A used clickers during the third and fourth weeks of the process. Their participation is outlined in Figure 2. 


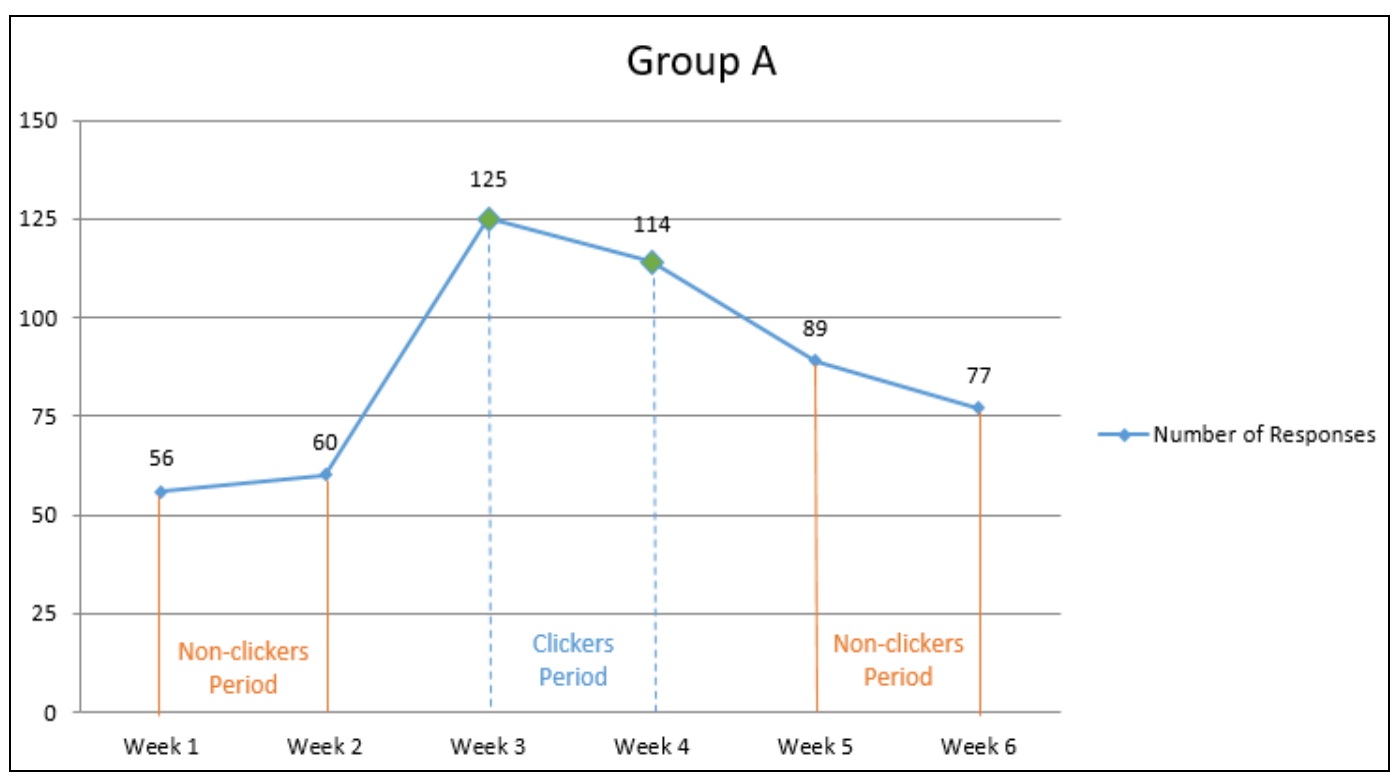

Figure 2. Change in the Participation Rates of the Students in Group A

Figure 2 reflects that while using clickers, the students in Group A participated in answering questions 125 times in the third week and 114 times in the fourth week-the highest values of participation. For the students in Group B, response frequencies are presented in Figure 3.

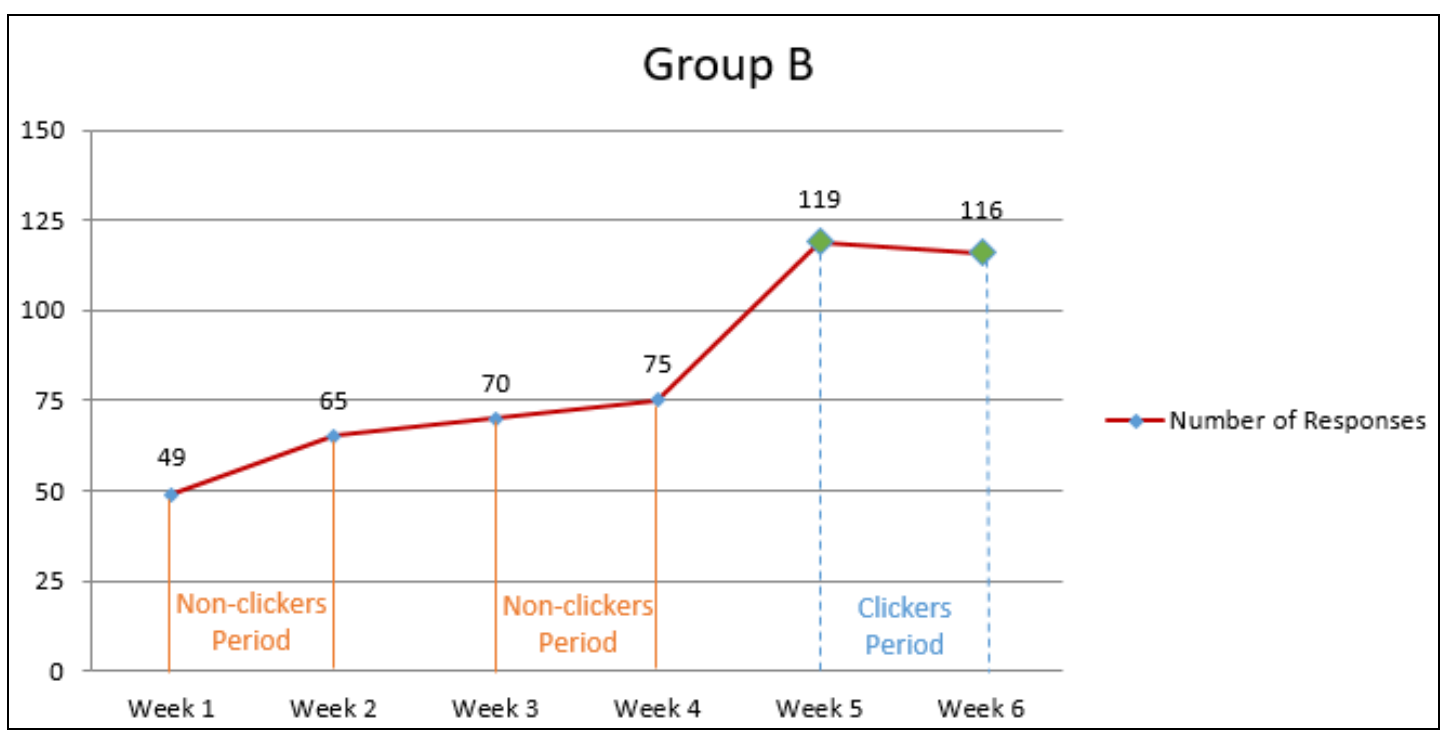

Figure 3. Change in the Participation Levels of the Students in Group B

Figure 3 indicates that the highest number of responses were in the fifth (119 times) and sixth (116 times) weeks. In the third and fourth weeks, when Group B did not use clickers, response numbers were low. A comparison of Group A's and Group B's response frequencies is presented in Figure 4. 


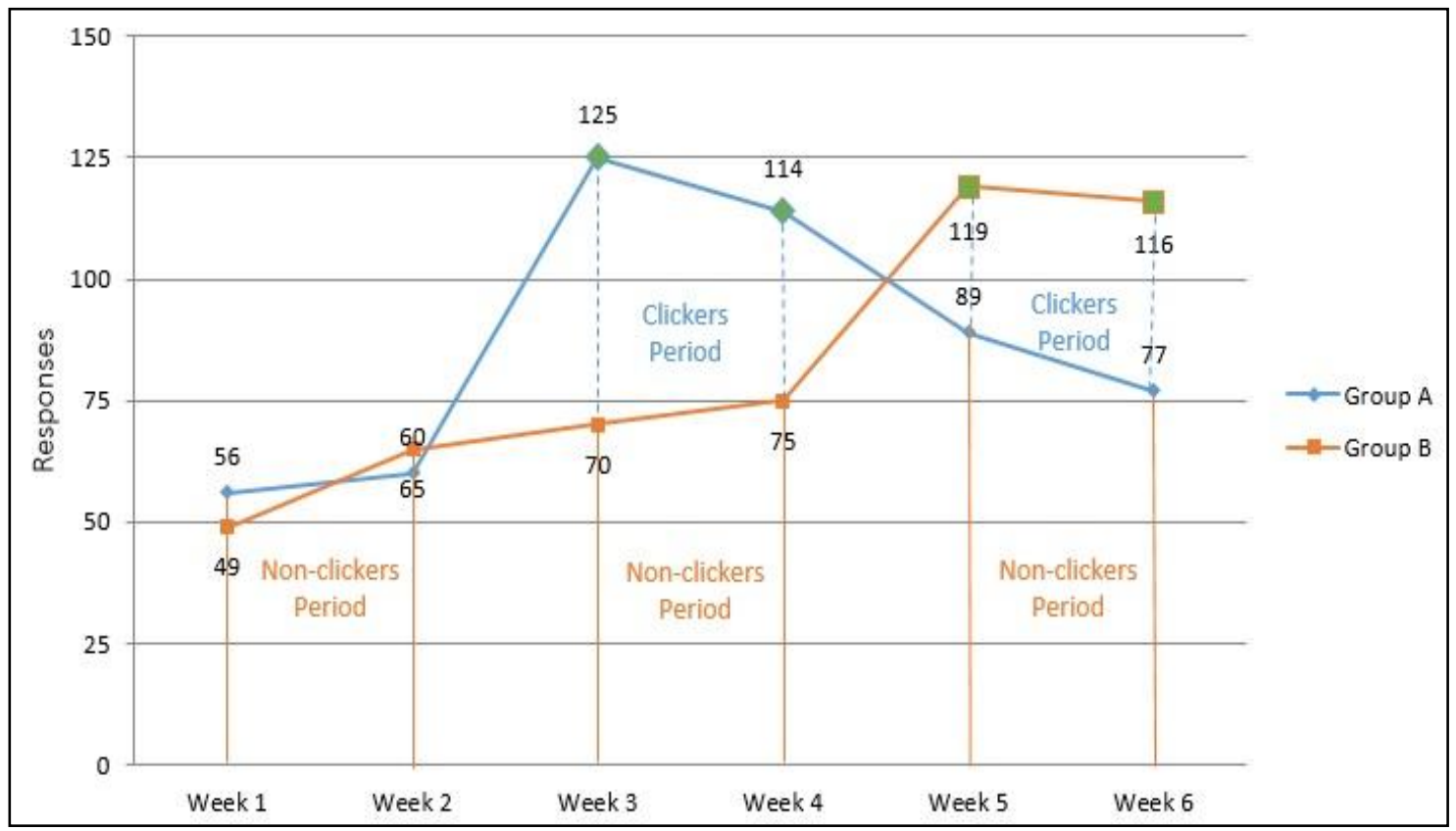

Figure 4. Comparison of the Participation Rates between Group A and B

The comparison in Figure 4 reveals an inverse relation between Groups $A$ and $B$ during the third and fourth weeks. Thus, while using clickers in different periods, both Groups A and B increased their participation rates. Surprisingly, differences in the number of responses in the third and fourth weeks between Groups A and B (125-70, 114-75, respectively) were somehow higher than those differences of the groups in the fifth and sixth weeks (119-89, 116-77, respectively). The Mann-Whitney test was conducted to determine whether there was a significant difference between the numbers of answers given by the two groups for the first period or not (Table 1).

Table 1. The Relationship between the Participation Rates of Group A and B in First Period

\begin{tabular}{|rl|r|r|r|r|c|}
\hline & Group & \multicolumn{1}{|c|}{ N } & \multicolumn{1}{|c|}{ M } & Sum of Ranks & U & p \\
\hline First Period & Group A & 10 & 12.70 & 127.00 & & \\
& Group B & 10 & 8.30 & & & \\
& Total & 20 & & & & \\
\hline
\end{tabular}

When Table 1 is examined, it is emerged that there is no significant differences between the numbers of answers given by the Group $A$ and $B$ during first period $(U=28.00, p>0.05)$. However, considering the sum of ranks, Group A (using clickers) seems to respond more to the questions than Group B (non-clickers). In addition, Table 2 shows the relationship between the participation rates in second period. 
Table 2. The Relationship between the Participation Rates of Group A and B in First Period

\begin{tabular}{|ll|r|r|r|r|c|}
\hline & Group & \multicolumn{1}{|c|}{ N } & \multicolumn{1}{c|}{ M } & Sum of Ranks & U & p \\
\hline Second & Group A & 10 & 9.00 & 90.00 & & \\
Period & Group B & 10 & 12.00 & 120.00 & 35.00 & 0.256 \\
& Total & 20 & & & & \\
\hline
\end{tabular}

Table 2 indicates that there is no significant differences between the numbers of answers given by the Group $A$ and $B$ during second period $(U=35.00, p>0.05)$. However, considering the sum of ranks, Group B (using clickers) seems to respond more to the questions than Group A (non-clickers).

A weekly analysis using descriptive data is also conducted in order to reveal weekly change in two groups. Thus, each participant's responses are symbolized in Figure 5 which outlines the frequency distribution of responses by Groups A and B.

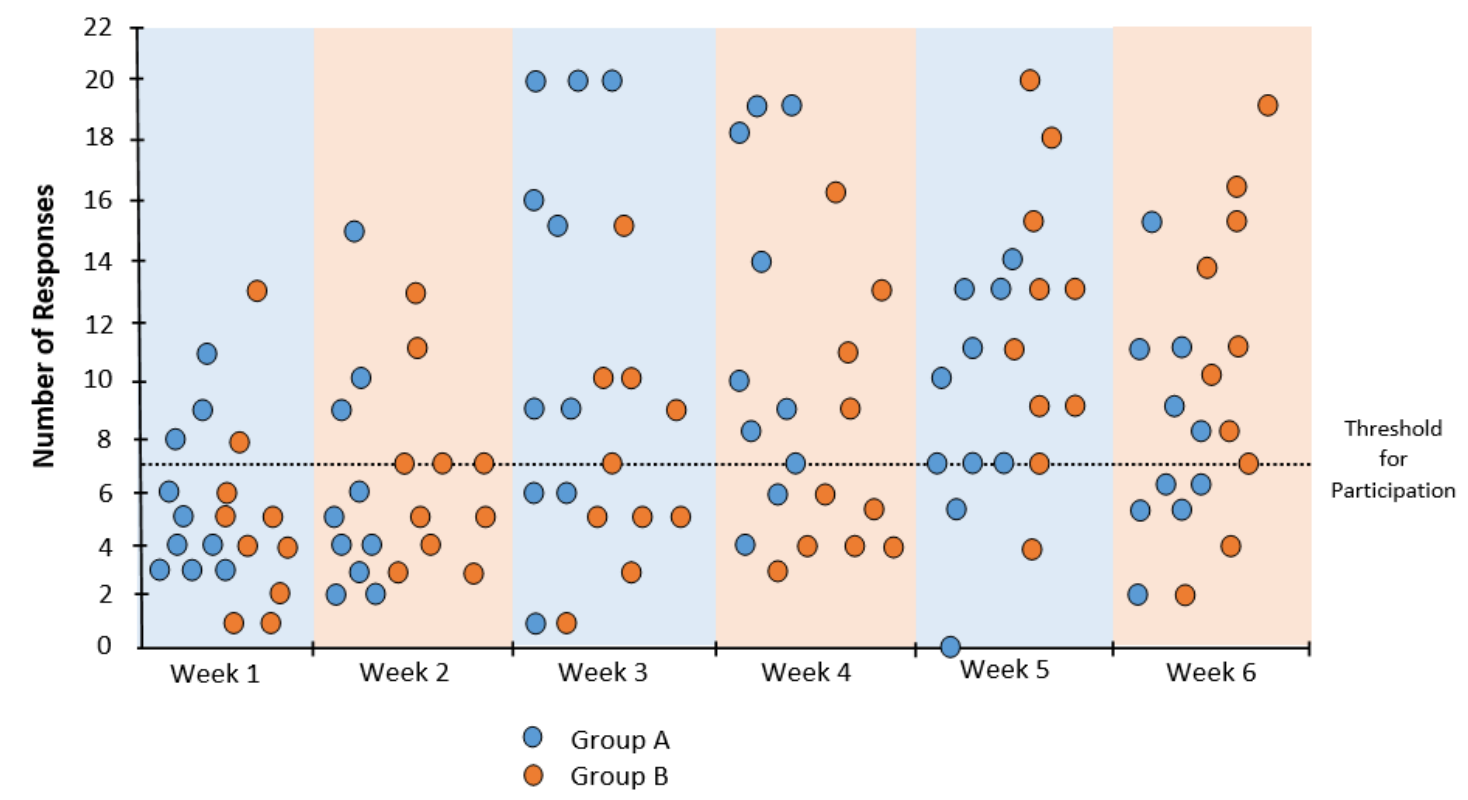

Figure 5. Weekly Participation Rates and Changes

Figure 5 indicates that during in the preparation period (when none of the groups was using clickers), response rates were concentrated at fewer than seven. Thus, seven responses were established as a threshold level. Group A's responses showed an increase during the first period (third and fourth weeks) and a decrease during the second period (fifth and sixth weeks). Additionally, in the second period, Group B's response rates increased, showing that having used clickers continued to affect participation positively even after the students stopped using them.

However, clicker users' response accuracy is also crucial because some students might have clicked buttons just to play rather than respond seriously. In this context, response accuracy was analyzed, with results illustrated in Figure 6. 


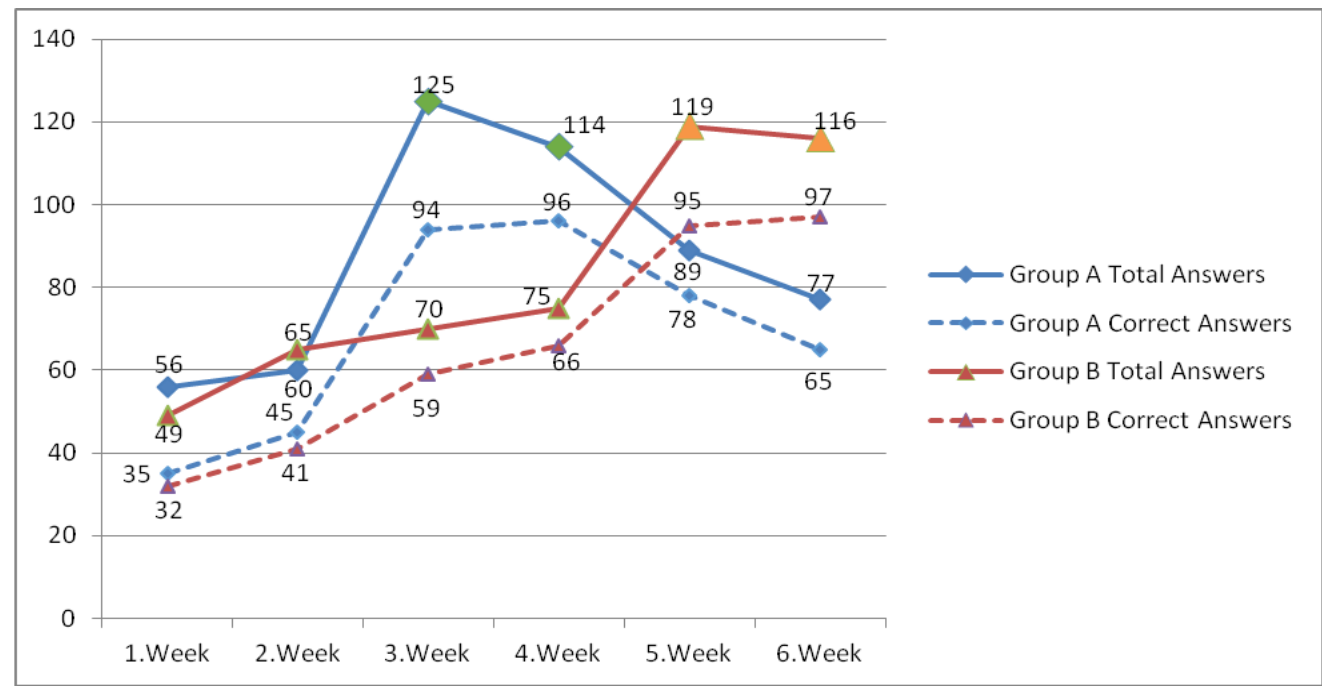

Figure 6. Weekly Quality of Responses

Responses in Figure 6 reveal that Group A clicker users had a higher participation level than those in Group B during the first experimental period. However, during the second experimental period (when the students in Group A were non-clickers), their rates of correct answers decreased. In contrast, when the students in Group B were non-clickers, it is seen that their correct answers increased.

\section{Discussion and Conclusion}

The experimental data show that the different use of clickers in the instructional processes descriptively have emerged some different participation rates in three phases of the experiment. In the first and second weeks (a preparation period without clickers), the two groups' participation rates were almost similar. In all periods, only a few students' participation levels were higher or lower than those of other students. In other words, these students' methods of response-via traditional strategies or clickers-did not change their participation rates overall.

This study's results indicated that although there is no significant difference between participation rates of Group A and B in the first period, Group A's participation rates when using clickers during the third and fourth weeks increased when compared with those during the preparation period. However, when they stopped using clickers in the fifth and sixth weeks, their participation rates decreased again. Similarly, Group B's participation rates during the third and fourth weeks were higher than those during the preparation period and reached the highest levels during the fifth and sixth weeks. Thus, those students with low self-esteem, anxiety about giving wrong answers, or communication problems might have been encouraged by clickers, which can eliminate the necessity for direct contact with the instructor and protect their anonymity with classmates. In the second experimental period, although there are no significant difference between participation rates of Group A and B in the second period, Group A's response rates decreased to a certain level. Nonetheless, their response rates during the second period were still higher than that during the preparation period. Interestingly, even 
when students ceased using clickers, the positive effect continued. Moreover, although Group $\mathrm{B}^{\prime} \mathrm{s}$ participation rates increased from the preparation period to the first experimental period, this increase may depend on the competition within the classroom caused by Group A's clicker use.

Surprisingly, when each group began to use clickers, reluctant students' response rates increased, thus leading to the conclusion that reluctant students' participation rates increased more than those of active students. In addition, the two groups' participation rates in the preparation period were lower than those during the last two weeks (fifth and sixth), confirming that students' high participation occurred not only when they used clickers but also following clicker use. In other words, starting with or without clickers can provide similar effects on the students' participation rates. One of this study's contributions is providing evidence about response quality. In the study's third and fourth weeks, Group A's correct answers increased in parallel with the total answers, and they provided more correct answers than Group B. In the fifth and sixth weeks, Group A's correct answers decreased, whereas Group B's increased. Altogether, this information reveals that students used clickers deliberately for learning, not just for play.

Furthermore, because interactivity facilitates learners' use of language in authentic communication (Agbatogun, 2012), interaction and active participation can help students take responsibility for their learning in EFL courses. By using clickers to ensure their participation, students interacted positively in this study. Similarly, in Cardoso's (2011) study of an EFL course, students perceived that clickers increased their participation, and their attitudes toward using clickers were generally positive. Other benefits of using clickers included contributing to learning, fostering interactions, and allowing learners to self-assessment and compare self-performances with those of their peers. Additionally, students with low selfesteem about communication participated in question-answer sessions via clickers, and the anonymity of clicker use somehow enhanced their self-esteem. As Heaslip et al. (2014) noted, when students raise their hands to answer questions or give a wrong answer, classmates might mock them, negatively affecting their willingness to participate.

Considering benefits of the clickers in the classrooms, $\mathrm{Yu}$ (2015) asserted that their use made EFL classes dynamic, so students could be active. Similarly, in this study, clickers dynamically and positively affected the entire class. This situation was generally independent from the period of clicker use, that is, regardless of using clickers after a non-clicker using period or beginning the lesson with clickers. Students who used clickers provided more answers and participated in the lesson more than others. This study confirms previous studies' similar findings (Addison, Wright, \& Milner, 2009; Crews et al., 2011; Fies \& Marshall, 2008; Preszler, Dawe, Shuster, \& Shuster, 2007; and Stowell \& Nelson, 2007). These researchers observed that passive students' participation rates increased and active students' interest and motivation were enhanced. Similarly, Premuroso, Tong, and Beed (2011) and Morse et al. (2010) reported that clickers' positively effect on participation. Additionally, some other electronic tools have been used to enhance EFL course participation. For instance, Wijtmans, Rens, and MuijlwijkKoezen (2014) and Wash (2014) preferred Socrative, an application for smart boards. Johns (2015) used Kahoot, a similar application, as a response tool. However, by providing competition within the classroom, clickers somehow affected positive differences in participation. 
This study also has some limitations. Although the instructor warned students about irrelevant clicker use, he could not entirely control it. Moreover, sample size is too small and is by no means for generalization. However, it provided hints to understand the effect of different use of the clickers in the lessons. The results also draw a picture for the other factors related to the effective use of clickers in the classrooms. Consequently, this study provided some considerable implications for teaching EFL via question-answer sessions using clickers. First, to accustom students to responding via clickers, instructors should allow them to use clickers for a limited period. Second, instructors should take some precautions so that students are discouraged from using clickers for irrelevant answers, perhaps by controlling the quality of answers during a given period. Third, role swapping, as in this study, might continue students' increased participation rates even after they discontinue using clickers. Overall, the study supported the idea that clickers can increase both students' class participation and their response accuracy, so instructors should concentrate on designing quality question-answer sessions to enhance learners' participation.

The study have some recommendations for future research and practice. In order to provide more generalizable results, a large size of sample may be considered in the future studies. In addition to this, it is possible to conduct studies with longer clickers using time to reduce the novelty effect. It is hoped that the study may provide some insights for using clickers in the activities of EFL classrooms.

\section{References}

Agbatogun, A. O. (2012). Enhancing second language skills development using student response system. In European Conference on e-Learning (p. 1). Academic Conferences International Limited.

Addison, S., Wright, A., \& Milner, R. (2009). Using clickers to improve student engagement and performance in an introductory biochemistry class. Biochemistry and Molecular Biology Education, 37(2), 84-91.

Bartsch, R. A. \& Murphy, W. (2011). Examining the effects of an electronic classroom response system on student engagement and performance. Journal of Educational Computing Research, 44(1), 25-33.

Blood, E. \& Neel, R. (2008). Using student response systems in lecture-based instruction: Does it change student engagement and learning? Journal of Technology and Teacher Education, 16(3), 375-383.

Cardoso, W. (2011). Learning a foreign language with a learner response system: The students' perspective. Computer Assisted Language Learning, 24(5), 393-417.

Carnaghan, C., Edmonds, T. P., Lechner, T. A., \& Olds, P. R. (2011). Using student response systems in the accounting classroom: Strengths, strategies and limitations. Journal of Accounting Education, 29(4), 265-283.

Carnaghan, C. \& Webb, A. (2007). Investigating the effects of group response systems on student satisfaction, learning, and engagement in accounting education. Issues in Accounting Education, 22(3), 391-409. 
Castillo-Manzano, J. I, Castro-Nuño, M., Díaz, M. T. S. \& Yñiguez, R. (2015). Does pressing a button make it easier to pass an exam? Evaluating the effectiveness of interactive technologies in higher education. British Journal of Educational Technology, 47(4), 710720

Chui, L., Martin, K. \& Pike, B. (2013). A quasi-experimental assessment of interactive student response systems on student confidence, effort, and course performance. Journal of Accounting Education, 31(1), 17-30.

Crews, T. B., Ducate, L., Rathel, J. M., Heid, K., \& Bishoff, S. T. (2011). Clickers in the classroom: Transforming students into active learners. ECAR Research Bulletin, 9, 502.

Dancer, D. \& Kamvounias, P. (2005). Student involvement in assessment: A project designed to assess class participation fairly and reliably. Assessment \& Evaluation in Higher Education, 30(4), 445-454.

Egelandsdal, K., \& Krumsvik, R. J. (2017). Clickers and formative feedback at university lectures. Education and Information Technologies, 22(1), 55-74.

Edmonds, C. T. \& Edmonds, T. P. (2010). An examination of the links between SRS technology and an active learning environment in a managerial accounting course. Advances in Accounting Education: Teaching and Curriculum Innovations, 11, 81-100.

Eisenbach, R., Golich, V. \& Curry, R. (1998). Classroom assessment across the disciplines. New Directions for Teaching and Learning, 1998(75), 59-66.

Fies, C., \& Marshall, J. (2008). The C3 framework: evaluating classroom response system interactions in university classrooms. Journal of Science Education and Technology, $17(5), 483-499$.

Heaslip, G., Donova, P. \& Cullen, J. P. (2014). Student response systems and learner engagement in large classes. Active Learning in Higher Education, 15(1), 11-24.

Hoekstra, A. (2008). Vibrant student voices: Exploring effects of the use of clickers in large college courses. Learning, Media and Technology, 33(4), 329-341.

Johns, K. (2015). Engaging and assessing students with technology: A review of kahoot. Delta Kappa Gamma Bulletin, 81(4), 89.

Kay, R. H. \& LeSage, A. (2009). Examining the benefits and challenges of using audience response systems: A review of the literature. Computers and Education, 53(3), 819-827.

Kenright, K. (2009). Clickers in the classroom. TechTrends, 53(1), 74-77.

Keough, S. M. (2012). Clickers in the classroom: A review and a replication. Journal of Management Education, 36(6), 822-847.

Lantz, M. E. (2010). The use of 'clickers' in the classroom: Teaching innovation or merely an amusing novelty?. Computers in Human Behavior, 26(4), 556-561.

Lasry, N. (2008). Clickers or flashcards: Is there really a difference?. The Physics Teacher, 46(4), $242-244$

Lee, Chong Min \& Oh, Eunjou. (2014). Exploring the effects of a learner response system on EFL reading. Multimedia-Assisted Language Learning, 17(2), 130-151

Liu, C., Chen, S., Chi, C., Chien, K-P., Liu, Y., \& Chou, T.-L. (2016). The effects of clickers with different teaching strategies. Journal of Educational Computing Research. 54(6), 1-26 
MacGeorge, E. L., Homan, S. R., Dunning, J. B. Jr, Elmore, D., Bodie, G. D., Evans, E., Khichadia, S., Lichti, S.M., Feng, B., \& Geddes, B.(2008). Student evaluation of audience response technology in large lecture class. Educational Technology Research and Development, 56(2), 125-145.

Marlow, D. W. (2010). Engaging syntax: Using a personal response system to encourage grammatical thought. American Speech, 85(2), 225-237.

Martyn, M. (2007). Clickers in the classroom: An active learning approach. Educause Quarterly, 30(2), 71.

Mayer, R. E., Stull, A., DeLeeuw, K., Almeroth, K., Bimber, B., Chun, D., Bulger, M., Campbell, J., Knight, A., \& Zhang, H. (2009). Clickers in college classrooms: Fostering learning with questioning methods. Contemporary Educational Psychology, 34(1), 51-57.

Morling, B., McAuliffe, M., Cohen, L. \& DiLorenzo, T. M. (2008). Efficacy of personal response systems ("clickers") in large, introductory psychology classes. Teaching of Psychology, 35(1), 45-50.

Mula, J. M. \& Kavanagh, M. (2009). Click go the students, click-click-click: The efficacy of a student response system for engaging students to improve feedback and performance. e-Journal of Business Education \& Scholarship of Teaching, 3(1), 1-17.

Mun, W. K., Hew, K. F. \& Cheung, W. S. (2009). The impact of the use of response pad system on the learning of secondary school physics concepts: A Singapore quasi-experiment study. British Journal of Educational Technology, 40(5), 848-860.

Morse,J., Ruggieri, M., \& Whelan-Berry, K. (2010). Clicking our way to class discussion. American Journal of Business Education, 3(3), 99-108.

Nelson, M. L., \& Hauck, R. V. (2008). Clicking to learn: A case study of embedding radiofrequency based Response Systems in an introductory management information systems course. Journal of Information Systems Education, 19(1), 55-64.

Phelps, R. P. (2012). The effect of testing on student achievement, 1910-2012. International Journal of Testing, 12(1), 21-43.

Premuroso, R., Tong, L., \& Beed, T. (2011). Does using Response Systems in the classroom matter to student performance and satisfaction when taking the introductory financial accounting course? Issues in Accounting Education, 26(4), 701-723.

Preszler, R.W., Dawe, A., Shuster, C.B. \& Shuster, M. (2007). Assessment of the effects of student response systems on student learning and attitudes over a broad range of biology course. CBE-Life Sciences Education. 6(1), 29-41.

Reschly, A. L., \& Christenson, S. L. (2006). Research leading to a predictive model of dropout and completion among students with mild disabilities and the role of student engagement. Remedial and Special Education, 27(5), 276-292.

Robinson, S. (2006). Using games and clickers to encourage students to study and participate. Proceedings of the Academy of Educational Leadership, 11(2), 25-29.

Rocca, K. A. (2010). Student participation in the college classroom: An extended multidisciplinary literature review. Communication Education, 59(2), 185-213. 
Ross, S. M., Morrison, G. R., \& Lowther, D. L. (2010). Educational Technology Research Past and Present: Balancing: Rigor and Relevance to Impact School Learning. Contemporary Educational Technology, 1(1), 17-35.

Schell, J., Lukoff, B., \& Mazur, E. (2013). Catalyzing learner engagement using cutting-edge classroom response systems in higher education. Cutting-edge Technologies in Higher Education, 6(1), 233-261.

Scott, V. (2014). Clicking in the Classroom: Using a student response system in an elementary classroom. New Horizons for Learning, 11(1), 1-11.

Stowell, J. R., \& Nelson, J. M. (2007). Benefits of electronic audience response systems on student participation, learning, and emotion. Teaching of psychology, 34(4), 253-258.

Stuart, S. A. J., Brown, M. I. \& Draper, S. W. (2004). Using an electronic voting system in logic lectures: One practitioner's application. Journal of Computer Assisted Learning, 20(2), 95-102.

Snyder, K. D. (2003). Ropes, poles, and space. Active Learning in Higher Education, 4(2), 159167.

Sun, J. (2014). Influence of polling technologies on student engagement: An analysis of student motivation, academic performance, and brainwave data. Computers \& Education, 72(2), 80-89.

Trees, A. R. \& Jackson, M. H. (2007). The learning environment in clicker classrooms: student processes of learning and involvement in large university-level courses using student response systems. Learning, Media and Technology, 32(1), 21-40.

Wijtmans, M., van Rens, L., \& van Muijlwijk-Koezen, J. E. (2014). Activating students' interest and participation in lectures and practical courses using their electronic devices. Journal of Chemical Education, 91(11), 1830-1837.

Yourstone, S. A., Kraye, H. S. \& Albaum, G. (2008). Classroom questioning with immediate electronic response: Do clickers improve learning? Decision Sciences Journal of Innovative Education, 6(1), 75-88.

Yu, Z. (2015). Indicators of satisfaction in clickers-aided EFL class. Frontiers in psychology, 6. doi: 10.3389/fpsyg.2015.00587.

Correspondence: Fatih Erdogdu, Research Assistant, Department of Computer Education and Instructional Technology, Fatih Faculty of Education, Karadeniz Technical University, Trabzon, Turkey 